\title{
Psychomotor developmental delay and epilepsy in an offspring of father-daughter incest: quantification of the causality probability
}

\author{
Leo P. ten Kate
}

Received: 27 March 2009 /Accepted: 15 July 2009 /Published online: 11 August 2009

(C) The Author(s) 2009. This article is published with open access at Springerlink.com

Schmidtke and Krawczak [1] described a patient with developmental delay and epilepsy who was the offspring of father-daughter incest, and showed that, based on available medical records and the baseline risk of the disorder in the population, the probability that the incest was causal for her disorder exceeded the $50 \%$ cutoff above which she would be entitled to a lifelong pension under the German federal act of victim indemnification. Their case was complicated by the absence of a clear specific diagnosis and the absence of permission for diagnostic workup.

This letter is not meant to criticize their calculations but to expand their work and cover other, less complicated cases. One of the possibilities the authors mention in their case report is a diagnosis of an autosomal recessive infantile epilepsy syndrome. It is easily shown that this diagnosis and, in fact, every diagnosis of an autosomal recessive disorder in the offspring of father-daughter incest is associated with a probability over $50 \%$ that the incest was causal for the disorder in the offspring. This also applies to a wide range of consanguineous matings whether incestuous or not.

The frequency of an autosomal recessive disorder in the offspring of a consanguineous mating is given by the formula

$P_{1}=F q+(1-F) q^{2}$

\section{P. ten Kate $(\bowtie)$}

Department of Clinical Genetics and Institute for Health and Care Research (EMGO+), VU University Medical Center,

Amsterdam, The Netherlands

e-mail: lp.tenkate@vumc.nl in which $F$ is the probability for autozygosity at the relevant gene locus and $q$ is the population frequency of a pathogenetic allele at this gene locus. $F$, which is also called the inbreeding coefficient, is one fourth in fatherdaughter incest, one eighth in grandfather-granddaughter incest, and $1 / 16$ in a first-cousin union.

In this formula, the first part $(F q)$ denotes the absolute probability that the disorder occurs as a result of the consanguinity of the parents, while the second part, $[(1-F)$ $q^{2}$ ], represents the absolute probability that the disorder was not a consequence of the consanguinity but of another cause [2]. So, the relative probability that a recessive disorder in the offspring of a consanguineous union is causally related to the consanguinity of the parents is

$P_{2}=F q /\left[F q+(1-F) q^{2}\right]$

When $F=1 / 4$, the critical value of $q$ is $1 / 3$, which means that $P_{2}$ is only smaller than $50 \%$ when $q$ is greater than $1 / 3$. To the best of my knowledge, such high values of $q$ do not exist in the general population for pathogenetic alleles causing autosomal recessive disorders. One of the highest known values is the allele frequency in the case of hemochromatosis, but this is still below $10 \%[3,4]$.

In general, alleles causing an autosomal recessive disease are rare. The allele frequency of cystic fibrosis, which is one of the most common recessive disorders, is generally quoted as being $1 / 50$. At this allele frequency, the probability that cystic fibrosis in an offspring of fatherdaughter incest is the result of this incestuous union is $94 \%$. For grandfather-granddaughter incest, this falls to $88 \%$. In a first-cousin union, it is $77 \%$. With smaller allele frequencies, these percentages become higher. 
The calculations presented here are not new. However, they illustrate the point that having a clear specific diagnosis results in greater certainty about the causality relation, although this may not always be favorable for the patient claiming victim indemnification.

Open Access This article is distributed under the terms of the Creative Commons Attribution Noncommercial License which permits any noncommercial use, distribution, and reproduction in any medium, provided the original author(s) and source are credited.

\section{References}

1. Schmidtke J, Krawczak M (2009) Psychomotor developmental delay and epilepsy in an offspring of father-daughter incest: quantification of the causality probability. Int $\mathrm{J}$ Legal Med. doi:10.1007/s00414-009-0337-8

2. Ten Kate LP, Scheffer H, Cornel MC, van Lookeren Campagne JG (1991) Consanguinity sans reproche. Hum Genet 86(3):295-296

3. Hanson EH, Imperatore G, Burke W (2001) HFE gene and hereditary hemochromatosis: a HuGE review. Human genome epidemiology. Am J Epidemiol 154:193-206

4. Bomford A (2002) Genetics of haemochromatosis. Lancet 360:1673-1681 